\title{
Emergence of Lamivudine Resistance Hepatitis B Virus Mutations in Pregnant Women Infected With HBV and HIV Receiving Antiretroviral Prophylaxis for the Prevention of Mother-to-Infant Transmission in Malawi
}

\author{
Clementina Galluzzo, ${ }^{1}$ Giuseppe Liotta, ${ }^{2,3}$ Mauro Andreotti, ${ }^{1}$ Richard Luhanga, ${ }^{4}$ Haswell Jere, ${ }^{4}$ \\ Sandro Mancinelli, ${ }^{2,3}$ Martin Maulidi, ${ }^{5}$ Jean-Baptiste Sagno, ${ }^{4}$ Maria Pirillo, ${ }^{1}$ Fulvio Erba, ${ }^{2,3}$ \\ Roberta Amici, ${ }^{1}$ Susanna Ceffa, ${ }^{3}$ Maria Cristina Marazzi, ${ }^{3,6}$ Stefano Vella, ${ }^{1}$ Leonardo Palombi, ${ }^{2,3}$ \\ and Marina Giuliano ${ }^{1 *}$ \\ ${ }^{1}$ Department of Therapeutic Research and Medicines Evaluation, Istituto Superiore di Sanità, Rome, Italy \\ ${ }^{2}$ Department of Public Health, University of Tor Vergata, Rome, Italy \\ ${ }^{3}$ DREAM Program, Community of S. Egidio, Rome, Italy \\ ${ }^{4}$ DREAM Program, Community of S. Egidio, Blantyre, Malawi \\ ${ }^{5}$ DREAM Program, Community of S. Egidio, Lilongwe, Malawi \\ ${ }^{6}$ LUMSA University, Rome, Italy
}

HIV/HBV co-infection is highly prevalent in subSaharan Africa. The aim of this study was to determine if the use of triple combination lamivudine-containing prophylaxis for the prevention of mother-to-infant HIV transmission was associated with the emergence of lamivudine HBV mutations. The study included 21 pregnant co-infected women in Malawi who received either zidovudine or stavudine plus lamivudine and nevirapine from week 25 of gestation until 6 months after delivery or indefinitely if they met the criteria for treatment (CD4+ <350/ $\mathrm{mm}^{3}$ ). HBV-DNA was determined using the Roche COBAS assay. Resistance mutations were assessed by the Trugene assay (Siemens Diagnostics). At baseline $33 \%$ of the women were $\mathrm{HBeAg}$ positive and had HBV-DNA $>10^{4} \mathrm{IU} / \mathrm{ml}$. Median CD4 count was 237 cells/ $\mathrm{mm}^{3}$ and median HIV-RNA was $3.8 \log _{10}$ copies/ml. After a median of 259 days of treatment, HBV-DNA was detectable in 9 out of 21 patients $(42.8 \%)$. In three cases the HBV-DNA level was $>10^{4} \mathrm{IU} / \mathrm{ml}$. Resistance mutations (M204l in five cases and $\mathrm{L} 180 \mathrm{M}+\mathrm{M} 204 \mathrm{I} / \mathrm{V}$ in one case) were present in $6(28.6 \%)$ patients. Women with a resistant virus had significantly higher baseline HBV-DNA levels than those not developing resistance $\left(1.1 \times 10^{7} \mathrm{IU} / \mathrm{ml}\right.$ vs. $20.8 \mathrm{IU} / \mathrm{ml}$, $P=0.022$ ). Levels of ALT and AST were higher in women with resistant viruses compared to those retaining a wild-type virus. A high rate of lamivudine resistance was seen in this cohort of pregnant women. Follow-up of these patients will clarify if the presence of resistance has a significant impact on liver disease. $J$.

Med. Virol. 84: 1553-1557, 2012.

(c) 2012 Wiley Periodicals, Inc.

KEY WORDS: HIV; HBV; drug resistance; lamivudine; Africa

\section{INTRODUCTION}

Co-infection with the hepatitis B virus (HBV) is highly prevalent among the HIV-infected population in sub-Saharan Africa [Modi and Feld, 2007]. The impact of $\mathrm{HBV}$ infection on the virological, immunological, and clinical outcome of HIV infection has not been elucidated completely. There are, however,

Grant sponsor: Istituto Superiore di Sanità, Rome, Italy; Grant number: 528c/28c7.

All authors have no conflict of interest.

Clementina Galluzzo and Giuseppe Liotta contributed equally to this study.

*Correspondence to: Marina Giuliano, MD, Department of Therapeutic Research and Medicines Evaluation, Istituto Superiore di Sanità, Viale Regina Elena, 299, 00161 Rome, Italy.

E-mail: marina.giuliano@iss.it

Accepted 7 June 2012

DOI 10.1002/jmv.23365

Published online in Wiley Online Library

(wileyonlinelibrary.com). 
reports showing similar outcomes in HIV-treated patients with and without $\mathrm{HBV}$ infection in some African countries, suggesting that there is no major influence [Hoffmann et al., 2008; Idoko et al., 2009].

Little information is available, in resource-limited settings, on the impact of HIV treatment on HBV disease. Since it is known that lamivudine monotherapy is associated with the emergence of drug resistance in a significant proportion of treated patients [Benhamou et al., 1999; Lok et al., 2003; Matthews et al., 2006], the most recent World Health Organization treatment guidelines [World Health Organization, 2010] recommend that, in the presence of HBV infection, tenofovir plus either lamivudine, or emtricitabine are included in the treatment regimen, if patients are in the need of treatment for the $\mathrm{HBV}$ infection. However, currently, the antiretroviral regimens used most commonly in African countries include zidovudine plus lamivudine and either nevirapine or efavirenz. Besides the difficulty to obtain tenofovir in many countries, patients are very rarely screened for HBV infection and, when screened, the determination of HBV-DNA to assess the need of treatment is not feasible in general.

Access to antiretroviral therapy is growing at increased speed in resource-limited settings and a high proportion of HIV-infected women is also attending the antenatal clinics and receiving treatment and care for the prevention of mother-to-infant transmission [Joint United Nations Program on HIV/AIDS, 2010].

The aim of the present study was to assess the impact of a lamivudine-containing antiretroviral prophylaxis on the emergence of lamivudine resistance in a cohort of breastfeeding women infected with $\mathrm{HBV}$ and HIV.

\section{MATERIALS AND METHODS}

\section{Patients}

The study included pregnant women infected with HBV and HIV enrolled between February 2008 and February 2009, in Malawi, in a study aimed to evaluate the safety and pharmacokinetics of antiretroviral drugs administered for the prevention of transmission of HIV by breastfeeding [Safe Milk for African Children (SMAC) study]. The study, conducted within the Drug Resource Enhancement against AIDS and Malnutrition (DREAM) Program, designed and managed by the Community of S. Egidio, was approved by the National Health Science Research Committee in Malawi. Written informed consent was obtained from all participating women. Women received a combination of either zidovudine (300 mg twice daily) or stavudine (30 mg twice daily) plus lamivudine (150 mg twice daily) and nevirapine (200 $\mathrm{mg}$ once daily for the first 14 days of treatment and $200 \mathrm{mg}$ twice daily thereafter) starting from week 25 of gestation (or as soon as possible for the women presenting at a later gestational age) until 6 months after delivery or indefinitely if they met the criteria for treatment $\left(\mathrm{CD} 4+<350 / \mathrm{mm}^{3}\right)$. Plasma samples were collected before the initiation of treatment and during treatment, 6 or 12 months after delivery. Liver function tests (alanine-aminotrasferase, ALT and aspartateaminotrasferase, AST) were monitored at each time point. In women interrupting treatment at 6 months postpartum, an additional plasma sample was collected between month 7 and month 12 .

\section{Virological Tests}

Women were tested using the Murex HBsAg Version 3 with Confirmatory Assay (Murex Biotech, Dartford, UK). The presence of HBeAg was assessed using the ARCHITECT HBeAg Reagent Kit (Abbott Diagnostics Division, Wiesbaden, Germany). Serum HBVDNA was quantified using the COBAS TaqMan HBV Test (Roche Molecular System, Branchburg, NJ) with a limit of quantification of $6 \mathrm{IU} / \mathrm{ml}$. The presence of $\mathrm{HBV}$ resistance mutations was assessed in women with HBV-DNA > $6 \mathrm{IU} / \mathrm{ml}$ by using the Trugene HBV Genotyping Kit (Siemens Healthcare Diagnostics, Deerfield, IL). A $1.2 \mathrm{~Kb}$ DNA fragment of the HBV [Surface Antigen (Sag) and Reverse Transcriptase (RT) regions] was amplified and sequenced to determine genotypes and drug resistance mutations. For HBV subgenotyping the bioinformatic algorithm geno2pheno (HBV) was used (http://hbv.bioinf.mpiinf.mpg.de/index.php).

\section{Data Analysis}

Descriptive values are expressed as absolute numbers, percentages and medians with interquartile ranges (IQRs). HBV-DNA values below the detection limit were assigned the value of $6 \mathrm{IU} / \mathrm{ml}$. Data were analyzed using the SPSS v.17.0 software package (SPSS, Chicago, IL).

\section{RESULTS}

A total of 21 women infected with $\mathrm{HBV}$ and $\mathrm{HIV}$ were studied. At baseline 13 women met the criteria for HIV treatment and started life-long antiretroviral therapy (ART) with stavudine plus lamivudine and nevirapine, the first-line regimen recommended in Malawi at the time of the study, while eight received zidovudine plus lamivudine and nevirapine prophylaxis until 6 months after delivery for the prevention of mother-to-child transmission, including post-natal transmission. Median age was 28 (IQR 23-30), median CD4+ count was 237 cells $/ \mathrm{mm}^{3}$ (IQR 187-491) and median HIV-RNA was $3.8 \log _{10}$ copies/ml (IQR $3.1-$ 4.5). At baseline 7 out of $21(33.3 \%)$ women were $\mathrm{HBeAg}$ positive and 6 out of 19 (31.6\%; for 2 women the information was missing) had HBV-DNA > $10,000 \mathrm{IU} / \mathrm{ml}$. Overall, $73.7 \%$ of the women (14 out of 19 with available information) had HBV-DNA > $6 \mathrm{IU} / \mathrm{ml}$. Only 1 patient had grade 1 AST elevation.

To detect the emergence of resistance during treatment all women were evaluated 6 months postpartum 
with the exception of three women, all on chronic therapy, who were evaluated 12 months after delivery. Overall, the median duration of ART was 259 days (IQR 234-308). At the time of the second evaluation all patients had HIV-RNA $<50$ copies $/ \mathrm{ml}$, and median CD4 count was 471 cells $/ \mathrm{mm}^{3}$. HBV-DNA was detectable in 9 out of 21 treated patients (42.8\%); however, only in 3 patients the HBV-DNA level was $>10^{4} \mathrm{IU} / \mathrm{ml}$. Resistance mutations (M204I in five cases and L180M + M204I/V in one case) were present in 6 patients $(28.6 \%$; Table I).

The presence of baseline mutations was assessed in the women developing resistance while on treatment: only one of the patients with the M204I mutation had the same mutation at baseline. Genotyping was performed in 12 patients, yielding 11 genotype A (all of them subgenotype A1), and 1 genotype E. All but one patient with a resistant virus were $\mathrm{HBeAg}$ positive. Women with a resistant virus had significantly higher baseline HBV-DNA levels compared to those harbouring viruses, which did not develop resistance $\left(1.1 \times 10^{7} \mathrm{IU} / \mathrm{ml}\right.$ vs. $\left.20.8 \mathrm{IU} / \mathrm{ml} P=0.022\right)$.

At the time of resistance testing grade 1 or $2 \mathrm{ALT} /$ AST elevations were present in 3 out of 6 patients with resistance and in 6 out of 15 patients without drug resistance; however, the 2 patients who had grade 2 toxicity had lamivudine resistance. Median levels of liver enzymes tended to be higher in patients with resistant viruses compared with those in patients retaining a wild-type virus $(P=0.036$ for AST and $P=0.066$ for ALT, respectively).
Among the eight women who discontinued treatment 6 months after delivery, seven were evaluated for HBV-DNA rebound between month 7 and 12 . Four of these seven women $(57.1 \%)$ were found to have a detectable HBV-DNA (between $2 \times 10^{2}$ and $1.1 \times 10^{8} \mathrm{IU} / \mathrm{ml}$ ). Only one patient had an M204I mutation (patient BC3440 who had the same mutation both at the baseline and at month 6). Liver enzymes for these women were evaluated at month 12 in all cases and in four cases also between month 7 and month 9. Only a grade 1 ALT and AST elevation was found in one patient at month 9 and in patient BC3440 at month 12.

\section{DISCUSSION}

With the expansion of antiretroviral programs to fight the HIV/AIDS epidemic, sub-Saharan African patients infected with HBV and HIV are gradually being exposed to lamivudine-containing therapies and, due to the low genetic barrier to resistance of lamivudine, a substantial proportion of these patients are at risk of HBV drug resistance.

This is the first study to assess the emergence of HBV lamivudine resistance in HIV-infected pregnant women who receive prophylaxis for the prevention of breastfeeding transmission. The data show that emergence of resistance is common in these women and that resistance is associated with a higher level of AST/ALT after 6-12 months of treatment.

TABLE I. Patient Characteristics Pre- and During Therapy

\begin{tabular}{|c|c|c|c|c|c|c|c|c|c|}
\hline \multirow[b]{2}{*}{ Pt. no. } & & & & & & & & & \\
\hline & Age & $\begin{array}{l}\text { HBeAg } \\
\text { status }\end{array}$ & $\begin{array}{l}\mathrm{ALT} / \mathrm{AST} \\
(\mathrm{U} / \mathrm{L})\end{array}$ & $\begin{array}{l}\text { HBV-DNA } \\
\text { IU/mL }\end{array}$ & $\begin{array}{c}\text { Drug resistance } \\
\text { mutations }\end{array}$ & $\begin{array}{c}\text { HBV-DNA } \\
\text { IU/mL }\end{array}$ & $\begin{array}{l}\text { Drug Resistance } \\
\text { mutations }\end{array}$ & $\begin{array}{l}\text { ALT/AST } \\
\text { (U/L) }\end{array}$ & $\begin{array}{l}\text { Time point of } \\
\text { HBV-DNA } \\
\text { and resistance } \\
\text { determination }\end{array}$ \\
\hline BC4067 & 20 & $\mathrm{Neg}$ & $10 / 38$ & $<6$ & - & $<6$ & - & $8 / 35$ & Month 6 \\
\hline BC3875 & 36 & $\mathrm{Neg}$ & $17 / 35$ & $<6$ & - & $<6$ & - & $13 / 35$ & Month 6 \\
\hline BC4064 & 22 & Pos & $18 / 29$ & $>1.1 \times 10^{8}$ & None & $5.4 \times 10^{2}$ & M204I & $140 / 85$ & Month 6 \\
\hline BC4566 & 28 & Neg & $13 / 28$ & 33.4 & - & $<6$ & - & $54 / 18$ & Month 6 \\
\hline BC3161 & 27 & Pos & $12 / 26$ & $>1.1 \times 10^{8}$ & None & $7.3 \times 10^{3}$ & L180M M204I/V & $21 / 27$ & Month 12 \\
\hline BC3163 & 27 & $\mathrm{Neg}$ & $11 / 15$ & 17.9 & - & $<6$ & - & $38 / 80$ & Month 6 \\
\hline BC3141 & 23 & $\mathrm{Neg}$ & $24 / 12$ & $<6$ & - & $<6$ & - & $63 / 38$ & Month 6 \\
\hline BC3616 & 23 & $\mathrm{Neg}$ & $15 / 23$ & $2 \times 10^{3}$ & None & $<6$ & - & $54 / 39$ & Month 6 \\
\hline BC3142 & 30 & Neg & $17 / 15$ & 21.1 & - & $<6$ & - & $27 / 19$ & Month 6 \\
\hline BC3440 & 37 & Pos & $19 / 20$ & $1.1 \times 10^{6}$ & M204I & $>1.1 \times 10^{8}$ & M204I & $43 / 46$ & Month 6 \\
\hline BC3777 & 29 & Pos & $34 / 85$ & $>1.1 \times 10^{8}$ & None & $4.7 \times 10^{4}$ & M204I & $80 / 57$ & Month 12 \\
\hline ВC3669 & 33 & Neg & $5 / 33$ & 38.1 & - & $<6$ & - & $14 / 35$ & Month 6 \\
\hline LW4920 & 29 & $\mathrm{Neg}$ & $23 / 38$ & 20.5 & - & $<6$ & - & $37 / 34$ & Month 12 \\
\hline BC5060 & 17 & $\mathrm{Neg}$ & $6 / 18$ & $<6$ & - & $<6$ & - & $26 / 31$ & Month 6 \\
\hline BC5953 & 30 & $\mathrm{Neg}$ & $14 / 28$ & 49.4 & - & 14.5 & None & $15 / 33$ & Month 6 \\
\hline BC5622 & 24 & $\mathrm{Neg}$ & $13 / 28$ & $2.6 \times 10^{2}$ & - & $<6$ & - & $51 / 56$ & Month 6 \\
\hline BC5190 & 30 & Pos & $28 / 37$ & $2 \times 10^{6}$ & - & $7 \times 10^{2}$ & None & $66 / 56$ & Month 6 \\
\hline BC6030 & 23 & Pos & $28 / 37$ & $6.8 \times 10^{5}$ & None & 55.8 & M204I & $67 / 116$ & Month 6 \\
\hline LW5768 & 28 & Pos & $32 / 38$ & NA & - & 73.1 & None & $18 / 24$ & Month 6 \\
\hline BC5187 & 26 & $\mathrm{Neg}$ & $7 / 16$ & NA & - & $<6$ & - & $16 / 18$ & Month 6 \\
\hline BC5235 & 25 & $\mathrm{Neg}$ & $13 / 27$ & $<6$ & - & $1.2 \times 10^{5}$ & M204I & $33 / 52$ & Month 6 \\
\hline
\end{tabular}

NA, not available. 
All but one strain in the current study belonged to genotype A (subtype A1) in agreement with previous studies conducted in Malawi [Sugauchi et al., 2003]. Although one study [Ramos et al., 2007] suggested that HBV genotype A tended to show lamivudine resistance mutations more often and to develop them earlier than patients with HBV genotype $D$, the results of the present study are in agreement with other reports of similar rates of resistance in the population infected with HBV and HIV treated with lamivudine monotherapy in different parts of the world [Benhamou et al., 1999; Cooley et al., 2003; Lok et al., 2003; Matthews et al., 2006; Mendes-Correa et al., 2010]. The emergence of resistance was significantly associated with baseline HBV-DNA confirming that the patients with high viraemia are those that could not benefit from lamivudine monotherapy [Soriano et al., 2008].

The presence of detectable HBV-DNA after 6-12 months of treatment was almost invariably associated with the emergence of resistance mutations and it therefore seems that adherence problems were not dominant in this cohort of patients as shown also by the fact that all women had undetectable HIV-RNA during follow-up. In one case a lamivudine resistant strain was present when the HBV-DNA level was $<100 \mathrm{IU} / \mathrm{ml}$, suggesting, as reported by others, that low viral replication cannot completely prevent the emergence of drug resistance [Svicher et al., 2010; Liu et al., 2011].

A lamivudine resistance mutation was found at baseline in only one woman subsequently developing mutations, although we cannot exclude that minority resistant variants pre-existed and were selected in the presence of lamivudine. In the present study not all women were tested at baseline however, the prevalence of baseline mutations seems lower compared to the small South African study showing a 50\% (10 out of 20) proportion of resistance at baseline [Selabe et al., 2007]. Although natural polymorphisms may also account for the presence of mutations [Kobayashi et al., 2001] these results nonetheless suggest there is a potential risk of drug-resistant HBV transmission. This can be particularly important for the triple mutant (V173L + L180M + M204V) strain that, in vitro, is known to behave as a vaccine escape mutant and can also be selected at a significant frequency during lamivudine monotherapy [Matthews et al., 2006]. These data therefore support the introduction of HBV screening in the HIV-infected pregnant women population in resource-limited settings.

A risk of hepatic flare exists at discontinuation of antiretroviral regimens containing HBV-active drugs in patients infected with HBV and HIV [Dore et al., 2010]. The data obtained from the women who interrupted the drugs 6 months after delivery showing no new emergence of resistance and no significative increase in liver enzymes, although limited, are reassuring in this sense.
Liver disease is a leading cause of mortality in HIVinfected patients on antiretroviral therapy in industrialized countries where $25 \%$ of the liver deaths can be attributed to an HBV infection [Weber et al., 2006]. The impact of HBV infection in the HIV-infected population in resource-limited settings has yet to be defined. In the present study the emergence of resistance mutations was associated with an increase in liver enzymes. Long-term follow-up of this cohort of women will clarify whether the emergence of resistance has a significant impact on liver disease.

\section{ACKNOWLEDGMENTS}

The authors wish to thank Maria Grazia Mancini for technical assistance, Alessandra Mattei for administrative work and Tonino Sofia for revising the manuscript.

\section{REFERENCES}

Benhamou Y, Bochet M, Thibault V, Di Martino V, Caumes E, Bricaire F, Opolon P, Katlama C, Poynard T. 1999. Long-term incidence of hepatitis $\mathrm{B}$ virus resistance to lamivudine in human immunodeficiency virus-infected patients. Hepatology 30:13021306

Cooley L, Ayres A, Bartholomeusz A, Lewin S, Crowe S, Mijch A, Locarnini S, Sasadeusz J. 2003. Prevalence and characterization of lamivudine-resistant hepatitis B virus mutations in HIV-HBV co-infected individuals. AIDS 17:1649-1657.

Dore GJ, Soriano V, Rockstroh J, Kupfer B, Tedaldi E, Peters L, Neuhaus J, Puoti M, Klein MB, Mocroft A, Clotet B, Lundgren JD. 2010. Frequent hepatitis B virus (HBV) rebound among HIV -HBV coinfected patients following antiretroviral therapy interruption in the SMART study. AIDS 24:857-865.

Hoffmann C, Charalambous S, Martin DJ, Innes C, Churchyard GJ, Chaisson RE, Grant AD, Fielding KL, Thio CL. 2008. Hepatitis B virus infection and response to antiretroviral therapy (ART) in a South African ART program. Clin Infect Dis 47:1479-1485.

Idoko J, Meloni S, Muazu M, Nimzing L, Badung B, Hawkins C, Sankalé JL, Ekong E, Murphy R, Kanki P, Thio CL. 2009. Impact of hepatitis $\mathrm{B}$ virus infection on human immunodeficiency virus response to antiretroviral therapy in Nigeria. Clin Infect Dis 49:1268-1273.

Joint United Nations Program on HIV/AIDS. 2010. Global Report: UNAIDS report on the global AIDS epidemic.

Kobayashi S, Ide T, Sata M. 2001. Detection of YMDD motif mutations in some lamivudine-untreated asymptomatic hepatitis B virus carriers. J Hepatol 37:259-265.

Liu Y, Wang C, Zhong Y, Li X, Dai J, Ren X, Xu Z, Li L, Yao Z, Ji D, Wang L, Zhang L, Wong VW, Zoulim F, Xu D. 2011. Genotypic resistance profile of hepatitis $B$ virus (HBV) in a large cohort of nucleos $(\mathrm{t})$ ide analogue-experienced Chinese patients with chronic HBV infection. J Viral Hepat 18:e29-e39.

Lok AS, Lai CL, Leung N, Yao GB, Cui ZY, Schiff ER, Dienstag JL, Heathcote EJ, Little NR, Griffiths DA, Gardner SD, Castiglia M. 2003. Long-term safety of lamivudine treatment in patients with chronic hepatitis B. Gastroenterology 125:1714-1722.

Matthews GV, Bartholomeusz A, Locarnini S, Ayres A, Sasaduesz J, Seaberg E, Cooper DA, Lewin S, Dore GJ, Thio CL. 2006. Characteristics of drug resistant $\mathrm{HBV}$ in an international collaborative study of HIV-HBV-infected individuals on extended lamivudine therapy. AIDS 20:863-870.

Mendes-Correa MC, Pinho JRR, Locarnini S, Yuen L, Sitnik R, Santana RA, Gomes-Gouvêa MS, Leite OM, Martins LG, Silva MH, Gianini RJ, Uip DE. 2010. High frequency of lamivudine resistance mutations in Brazilian patients co-infected with HIV and hepatitis B. J Med Virol 82:1481-1488.

Modi A, Feld J. 2007. Viral hepatitis and HIV in Africa. AIDS Rev 9:25-39.

Ramos B, Nunez M, Martin-Carbonero L, Sheldon J, Rios P, Labarga P, Romero M, Barreiro P, García-Samaniego J, Soriano V. 
2007. Hepatitis B genotypes and lamivudine resistance mutations in HIV/hepatitis B virus-co-infected patients. J Acquir Immune Defic Syndr 44:557-561.

Selabe SG, Lukhwareni A, Song E, Leeuw YG, Burnett RJ, Mphahlele MJ. 2007. Mutations associated with lamivudine-resistance in therapy-naive hepatitis B virus (HBV) infected patients with and without HIV co-infection: Implications for antiretroviral therapy in HBV and HIV co-infected South African patients. J Med Virol 79:1650-1654.

Soriano V, Rivas P, Nunez M. 2008. Risks and benefits of using antiretroviral therapy in HIV-infected patients with chronic hepatitis $\mathrm{B}$ in developing regions. Clin Infect Dis 47:1486-1489.

Sugauchi F, Orito E, Kato H, Suzuki S, Kawakita S, Sakamoto Y, Fukushima K, Akiba T, Yoshihara N, Ueda R, Mizokami M. 2003. Genotype, serotype, and phylogenetic characterization of the complete genome sequence of hepatitis B virus isolates from Malawian chronic carriers of the virus. J Med Virol 69:33-40.
Svicher V, Alteri C, Gori C, Salpini R, Marcuccilli F, Bertoli A Longo R, Bernassola M, Gallinaro V, Romano S, Visca M, Ursitti A, Feasi M, Micheli V, Angelico M, Cassola G, Parruti G, Gubertini G, De Sanctis GM, Ceccherini-Silberstein F, Cappiello G, Spanò A, Perno CF. 2010. Lamivudine-resistance mutations can be selected even at very low levels of hepatitis B viraemia. Dig Liv Dis 42:902-907.

Weber R, Sabin CA, Friis-Moller N, Reiss P, El-Sadr WM, Kirk O, Dabis F, Law MG, Pradier C, De Wit S, Akerlund B, Calvo G, Monforte A, Rickenbach M, Ledergerber B, Phillips AN, Lundgren JD. 2006. Liver-related deaths in persons infected with the human immunodeficiency virus: The D:A:D study. Arch Intern Med 166:1632-1641.

World Health Organization. 2010. Antiretroviral therapy for HIV infection in adults and adolescents: Recommendations for a public health approach. Available from: http://www.who.int/HIV/pub/ arv/adult2010/en/ 